\title{
Toward discerning community - based tourism
}

\author{
Nguyen Ngoc Tho
}

\begin{abstract}
CBT rooted some decades ago in the West and has currently been on the rapid rise thanks to the promotion of internet-based informatics. CBT tourists has shaped several driving forces and motivation to speed up the promotion and completion of CBT worldwide. Along with the boom of high-tech and its incredible pressures on human mind, post-modernism (PM) has been shaped due to the strong demand of liberalizing in human beings' mind and diversifying their lifestyles under the mutual interaction between ecological and cultural resources. PM starts firstly in arts and literature, gradually influences on business and tourism; hence impacts on CBT. The reconciliation of CBT and PM gives birth to discerning CBT advanced by discerning travelers who definitly care on their selfparticipation, self-experience, self-discovery during their journeys as well as the request for cooperation, co-controlling and co-responsibility of all the tourists, state agents and the local communities during the services. The discerning CBT travelers partially promote the commoners' awareness and engagement in advancing standard of life and civilizing of their lifestyle. Discerning CBT is surely not to replace popular CBT as a whole but to modify the diversity of modern tourism as it meets a concrete part of the various demands of tourists and pay more important role in standardizing human life.
\end{abstract}

Keywords-community-based tourism, postmodernism, discerning CBT, reconcilation, interaction

\section{WHAT MAKES COMMUNITY - BASED TOURISM?}

Community based tourism (CBT) originated in Western world in early $20^{\text {th }}$ century under various

Received: 12/12/2017, Accepted: 25/01/2018; Published: $30 / 3 / 2018$

Nguyen Ngoc Tho, University of Social Sciences and Humanities, VNU-HCM

Email: ngoctho@hcmussh.edu.vn definitions by theorists of different disciplines. Generally, CBT is a form of tourism that brings the travelers the knowledge and experience of the destination community in which the local residents get engaged directly in the tourism activities and absorb the economic-social values through the activities as well as pay the important role in protecting their ecologocial and cultural environments. Weaver $(2010,206)$ observes that community-based tourism (CBT) was referred to in the early $1980 \mathrm{~s}$ as the sine qua non of alternative tourists. CBT was once hopes "of combatting mass tourism in the developing world and aiding rural communities in the global south through grassroots development, resident participation, empowerment and capacity building" (Scheyvens 1999 \& 2002). Similarly, Peter Murphy (1985: 188) also states that "community tourism where "community" very broadly refers to a group of people living in a defined space, and visitors interact with local people and landscape for a tourism experience".

In reality, many precious ecological and cultural legacies of human kind have been endangered, the local communities are being harmed due to the recent poorly-organized popular tourism. CBT is the newly-flourishing way which enables the local residents to take part in controlling the operation and the development of their local tourism, they share the values and responsibilities in preserving the normality of tourism. CBT also promotes the activeness of the community in creating new values for tourism.

CBT is different from the popular tourism in two important aspects, respectively, size and economic ingredients. In popular tourism, the agents and networked service partners who invest, design, operate, control and earn directly the final values, CBT cares for households, artisans and handicraft makers since they are the main hosts to offer the service. In CBT, the travelers may or may not register with an agent for transportation 
TẠP CHÍ PHÁT TRIỂN KHOA HỌC \& CÔNG NGHỆ: CHUYÊN SAN KHOA HỌC XÃ HộI VÀ NHÂN VĂN, TậP 1, SỐ 1, 2018

and other infrastructure services (including the vibrancy of air-based transportation and mobile accommodation services like Airbnb), however, they would love to set up themselves the visits at the local places, talk and share the knowledge and skills with the artisans, the farmers and commoners. When being put in the centerpoint, the community are to be proud to work since they directly enrich their hometown by their own efforts.

In the current globalized perspective, CBT calls for the following features:

(1) Calling for Social equalization: Since the community members take part in making the plan, operating and managing the activities, the benefits are coshared by the community members and tourism agents. In CBT, agents, enterprises become community-owned and community-based tourism institutions that "enhances conservation and in which the local community is fully involved throughout its development and management and they are the main beneficiaries through community development" (Manyara, G.; Jones, E. 2007: 628-644).

(2) Respecting the local culture and natural heritage: under any form of tourism, ecological and cultural landscapes are under the visible and invisible pressures, only the community members are fully aware of the importance of these legacies to their life and how serious the damages bring them in life. Under any circumstance, they are always active to measure the achived and lost values as well as wise to adjust the tourism plan to meet both requirements: benefit and sustainable life (see also Leonard Barnett \& Edward G. L. Carter, 2013). The respect towards ecological and cultural resources has to be based on detailed features such as geography, climate, architecture, arts, cuisines, lifestyle etc. in which only the community understand them clearly than whoever.

(3) Balancing between benefit and responsibility: All participating partners (the agents, community) are all responsible for renewing, promoting and upgrading the services as well as infrastructure through CBT incomes. The preservation of landscapes and culture is strongly associated with the plan-making of CBT activities such as lodging, transportation, natural parks, etc.). "CBT is a type of sustainable tourism that promotes pro-poor strategies in a community setting. The CBT initiatives aim to involve local residents in the running and management of small tourism projects as a means of alleviating poverty and providing an alternative income source for community members" (Netherlands Development Organization (SNV) Asia Pro-Poor Sustainable Tourism Network, 2007).

(4) The community's ownership and participation: The community's participation in making plan, operating and managing the CBT activities is a real demonstration of the ownership by the community, this push them become more active in seeking and preserving the longlasting effects of CBT acitivities they get engaged in. Ellis, S. and Sheridan, L.M. (2014: 129-142) emphasize that CBT applies the objectives of sustainable tourism "combined with an emphasis on community engagement and development". "CBT is generally small scale and involves interactions between visitor and host community, particularly suited to rural and regional areas. CBT is commonly understood to be managed and owned by the community, for the community" (APEC Tourism Working Group, 2010). Similarly, Hall, C.M (1996), and Butler, R.; Curran, R.; O'Gorman (2013: 443-457) define that CBT is "an approach that engages the host community in the planning and development of the tourism industry". On the other hand, local elites are expected to be involving effectively during the process. Recent researches by James Watson (1985) and modified by Donald S. Sutton (2007), Michael Szonyi (2007), Paul Katz (2007), the local elites have been demonstrated as more than aggressive to manage the local community's agenda to well-fit the state-sponsored goals and the local community's diverse demands. The travelers can experience the diversity of the local culture as well as freely commit the interaction with the inhabitants. The community performs like the real "actors/actresses", they share the travelers the shinest characteristics of their cuisines, musics, folklore, custom, religion, craft village, lifestyle etc. under the most alive way. Both the travelers and the community are mutually treated by the respects.

(5) Peforming the sustainable operation in economy: $\mathrm{CBT}$ is one of the solution to decrease and abolish the normal tourism that harm seriously the economic, social and cultural life of the destinations. CBT calls for the fine combination between the ecological and cultural resources and between the community's target and travelers' interests in designing CBT activities. 
The community have to activate and evaluate the economic values of their landscapes as well as be active in comprehending the travelers' demand to build up the mutual interaction. "CBT refers to tourism that involves community participation and aims to generate benefits for local communities in the developing world by allowing tourists to visit these communities and learn about their culture and the local environment" (2012). Beside the financial income, CBT also brings driving forces and and advanced orientation for the community's development.

Althought there is still set of differnces between CBT and sustainable tourism such as scale of application, geographical distribution, commoditization level, transparency of profit sources, quantitative and qualitative approaches in the way effect is evaluated etc. (see Tek B. Dangi \& Tazim Jamal, 2016: 13), both have reconciled in modern CBT throughout Asia. According to the ethical tourism theory by Tribe (2006), the sustainability of tourism will be the basic trend in upcoming days. Eber (1992) stated that sustainable tourism "wisely uses and conserves resources in order to maintain their long-term viability. Essentailly, sustainable tourism involves the minimization of negative impacts nad maximization of active impacts" (see also Leonard Barnett \& Edward G. L. Carter, 2013). Sustainable tourism performs the creative role in nurturing and revitalizing resources for future tourism development rather than only exploiting the current resources. Sustainable tourism helps build the dialogue platform that the community learn to know the values of their culture and daily activities as well as obtain the more modernized and civilized lifestyle such as pursuing arts, aesthetics-based practices and responsible mindset by each individual. In sustainable tourism, all participating partners including the community, the agent and the travelers all are the winners to share the values. The World Tourism Organization defines that the sustainable tourism meets the demand of the tourists as well as the current tourism localities, simultaneously ensures the protection and promotion on future development (Tourism Institute, 2010). All the above-mentioned concepts are well adapted to the post-modern concept of post-materialistic value that stresses on the role and responsibility of each individual in taking effects the ethical behavior and obtaining the sustainable selection.

\section{WHAT CAN POSTMODERNISM HELP?}

Post-modernism is a term that is not accurately defined, but is often understood that "beyond the modern" or "be past the modern". For example, Lyotard in The Postmodern Condition (1984) proposes that a work can become modern only if it is first obtained post-modern standard. Therefore, post-modernism is not modern, it penetrates (or borrows) modern factors at the beginning but turns into other directions at the end. The postmodern probably tends to take the unpresentable in pragmatic manifestation itself. The artists, writers compose their unpatterned works only to "mold" the immutable rules that must be made "what will have been done". The post-modernism would have to be understood according to the paradoxy of future anterior, which attaches great importance to the distance from today to the future rather than idealistic appearance of "the future" itself. The post-modernism is not a continuation of the today but it can be anything close to the idea against or against the modernism popularized from the early 20 th century.

The New Oxford American Dictionary (1998) defined: "Post-modernism is a late 20th-century style and concept in the arts, architecture, and criticism that represents a departure from modernism and has at its heart a general distrust of grand theories and ideologies as well as a problematical relationship with any notion of art". The post-modernism has got the premise in between the two World Wars in the 20th century. Arnold Toynbee (1939) said: "Post-modern era began when World War I ended in 1914". C. Wright Mills (1959) stressed: "The postmodernism is the collapse of the Enlightenment ideas" while Amitai Etzioni (1968) considered it the result of transition in communication, knowledge and human capacity since the World War II. Many other Western authors directly or indirectly discuss the post-modernism such as Lyotards (1979), Hassan (1971) \& Bell (1976) etc.. Lyotards Bell (1984) suggests that the postmodernism should be essentially the search for instability. In reality, the premise that puts a direct influence on the post-modernism starts from the 1980s. Clifford Geertz (1983: 8) writes that most scientists have turned to the light of the language, aesthetic, history and culture, customary law or literary criticism rather than being sunk in researches, in mechanical invention, in engineering and physics as it had been before. The 
post-modernism, in opposite, pursues topics such as the cessation of metanarrative, the atrophy of topics and authors; the emphases of representation, surfaces, images, criticalness, parody, anti-poetry, collage, de-seriousness, unpredictability of context and interdependence of contexts - all are different from the true meanings of social reality. Marta \& Linda (1997) emphasize the post-modernism advocating the unknown ability including the true meaning of social reality. If modernism upholds the motto "dare to understand" or "dare to know", then postmodernism seems to uphold the banner that what we know is very little. According to Wilson, $\mathrm{R}$ (1991: 14-40), people during in the Enlightenment once thought they could get to know everything; the current post-modernists conversely claim "we can know nothing". Therefore, getting to know is the high-end demand of the postmodernist travellers.

The ideological foundation of the postmodernism has started from the explosion of sciences. Modern elements of questioning and problem-solving gradually form the regularity while the world of each individual's mind is an unpredictable "universe". Therefore, the postmodernism advocates each individual to seek the answers for their own. Post-modernism has directly melted down the diversity which is probably replaced by the survival of crossbreeding and cultural changes. We can take the Korean wave (Hallyu) as an example, dances of Gangnam Style, Gentlemen, Hello Korea, etc. are the particular representations of bricollage, collage and critical immitation in post-modern era. Similarly, the airline Virgin America has announced a video-clip on flight safety instructions by applying postmodern style, initially received a very positive reflection from the public.

The nature of post-modernism is the paradoxical juxtapositions. Post-modernism calls for being against racism, sexism, "Eurocentriism", bureaucraticism and colonialism. In return, it advocates the protection of people's interests with ulterior stories, of miserable and marginal people. Post-modernism may cause shocks to someone's but inspire the others. It is no doubt that postmodernism has brought the contemporary tourism the new taste and new movement. In common, one may state that PM produces the request for liberal and self-cultivated mindset which can reconcile with the recent $\mathrm{CBT}$ wave in modern world.

\section{DISCERNING CBT: THE HIGH-END COMBINATION OF CBT AND POSTMODERNISM}

We are living in an unpredictable changing world. All aspects of life are rapidly swinging, transforming and being reconstructed under new approaches, the travelers' demands are also. However, there have not been a complete academic survey on the change (what, how, why) on the demands and interests of the travelers implemented worldwide. The marvelous advancements of the world during previous century has produced a big jump in human wisdom, economic condition and lifestyle, thus the change of social responsibility also produces the change in the way we look and evaluate the world. In the post-modern society, those changes are clearer than ever, of course, the easilychanging tourism industry has been profoundly impacted. Due to the concept of inadequateness of academic depth and theoretical platform by many writers and readers, the researches on tourism have been underestimated during the last decades (Leonard Barnett \& Edward G. L. Carter, 2013). Many scholars argue that tourism is merely a management sector but not a wisdom-based industry, even being described as "an emptiness of wisdom".

Under the post-modernism's impacts, the "tourist gaze" (Urry, 2002) or the "medical gaze" (Foucault, 1980, Leonard Barnett \& Edward G. L. Carter, 2013) has been emphasized in worldwide tourism. This approach helps build in-depth theoretical platform and pay important role in promoting the tourism-centered researches by identifying the chronologically changeable essence and situation-based experience. Postmodernism seeks for a significant compromise in the modern era, in which PM meanings have been extracted from the world that the tourists get in touch with. Clearly, tourism is not merely a commercial activity or a lesson for business research but a profound, significant and optimistic pursuit. Presently, "mindless hedonism and pleasure seeking are no longer fashionable" (Singh, 2004). Similarly, in the postmodernism era, fordism-based tourism has been defashioned (Leonard Barnett \& Edward G. L. Carter, 2013). Post-moderinist travelers are different, they intend 
to find the possible meanings of living activities under the prism that the complicated cultural practices have been performed and organized in fornt of their eyes. Their surroundings, the local residents and the travelers themselves have all become the "real actors" in their experienced roleplays. In general, upon the rise of human wisdom, the demand and the interests of the travelers have been changed towards the in-depth participation, the self-participating performances in the living activities of the destination places.

In discerning CBT, the role of communal elites must play the core roles in determining the principles and the goals of the activities. Local elites, being demonstrated as clever to keep harmoniously the state-fostered direction and local cultural, economic expression. Michael Szonyi (2002), a Harvard University researcher, in his research on local religion and ritual manifestation in Fuzhou, China once said: "local literati as standing between local officials and local worshippers, in principle eager to do the will of the state but in practice covering up local variation and a welter of chaotic ritual expression". As a matter of fact, state-supported agents or private sectors mainly care for the administrative and/or economic values rather than the real and sustainable wealthy sources of the commoners. The state or state-fostered agents have never achieved a thoroughgoing dominance over cultural expression of the villages at any point in its history (see also Wong, R. Bin, Theodore Huters, and Pauline Yu, 1997: 23-24). In other aspect, local elites can wisely utilize local common ethic platform and communal goals to assert the legitimacy of the village's interests while the commoners partook of a trourism product manufactured by their elite leaders, both partners are activiely stabilizing their position in the process of standardization (or modernization) of their own lifestyle. It is the truth that without the guidlines and supports of the literati or the elite, the commoners' performances grow apart in various way (see also Kenneth Pomeranz 2007: 33). This actual combination of both top-down and bottom-up approaches of enriching communal wealthy reources and life-managing capacity has been demonstrated as successful model for at least the current period.

Under economic perspective, tourism is widely known as an important global economic industry. It creates millions of jobs and pay a large part in promoting GDP growth in each country. Presently, tourism is the worldleading rising industry (World Travel and Tourism Council, 2012). Tourism motivates the development of local products/activities, directly modernizing the local culture and widening the eyesights of the people (both the tourists and the local residents), all move towards the civilization target. Tourism help enrich the local authority's financial budget, thus creating opportunity to upgrade and develop the local infrastructure (transportation, market, services, telecommunication etc.). Under the social and cultural perspective, tourism hase promoted the educational opportunities, help build the multi-directional mindsets, help preserve the local cultural legacies and identitied; and at a certain level, it builds the capacity of performing the egoism and the awereness of humand rights. Cohen (1988: 371-386) in his paper "Authenticity and commoditization in tourism" once expresses that commoditization does not necessarily destroy the meaning of cultural products, although it may change it or add new meanings to old ones. MacCannell (1973) once states "commoditization is said to destroy the authenticity of local cultural products and human relations; instead a surrogate, covert "staged authenticity". The concept "authenticity" is used to characterize a criterion of evaluation used by the modern tourist as observer. "Tourists indeed appear to seek authenticity in varying degrees of intensity, depending on the degree of their alienation from modernity." (Cohen, 1988: 376). Both the local commoners and the tourist are unconsciously playing the staged game rather than a real touch. "Such processes of commoditization of culture for touristic purposes are oubtlessly quite common all over the Third World" (Cohen, 1988: 381). Under environmental perspective, post-modernist/ discerning tourism raises the attention on environment, the ecology and solutions for pollution elimination. Post-modernist travelers are aware of the fact that this blue sky is not for only humand kind but also homes of different species. The post-modernist travelers with new fashion of interests and demands have pushed the local government to invest more on environmentalism and look forward to the sustainable development (see also Leonard Barnett \& Edward G. L. Carter, 2013). At least, they help bring the progressive ideas on environmental protection. 
TẠP CHÍ PHÁT TRIỂN KHOA HỌC \& CÔNG NGHÊ:

CHUYÊN SAN KHOA HỌC XÃ HộI VÀ NHÂN VĂN, TậP 1, SỐ 1, 2018

Discerning CBT operates in different way from the popular tourism. Perionova (2005) states that discerning tourism is the post-modernist form of tourism that limit the number of travelers in designing the tourist activities to ensure the aims of values and highest benefits while Choibamroong (2003) points out the high-level intellectuals, the core customers of discerning traveling, who are called discerning travelers. MacCannell (1999) even describes the discerning travelers as the high-end "pilgrims" who wander to find the new lifestyle. They may be not so wealthy but they are fully aware of postmodernist values of tourism and always seek for them. In the new trend of discerning tourism, fordism has been coshared by post-modernism, the travelers are not only to see what is on but also would love to know how it will be in the future. Postmodernist discerning travelers really care for the environmental and moral responsibilities of all involving partners.

In term of age, fordism-based tourists are usually the "the mass travelers of the 1960s and 70 s, and are today's discerning and sophisticated travelers with the means and the will to travel" (Tepalus, 2000; Leonard Barnett \& Edward G.L. Carter, 2015). The concept of tourism is as "commoditization", among which local culture can be served as principal example (Greenwood, 1977) is left further behind. The contemporary high-end travelers care on the experience rather than the consumption, they love investigating the lively picture of the local culture, security condition, learning condition and adventurous spirits.

Discerning tourism can be seen as the combination of CBT and postmodernism, the former is basic structure and the later the in-depth manifestation and essence; however, there is still a distance between postmodern tourists and discerning tourists. Postmodern tourists measure the quality of life, lifestyle, freedom and health while the discerning CBT travelers are "more cultured than visitors of even 20 years ago, is well travelled, is searching for new experiences, is concerned about the environment, is interested in taking part in a health/wellbeing lifestyle and wants to experience the local culture when he goes on holiday." (Ian Yeoman, 2008: 195). The possible differences between CBT and discerning CBT can be summarized as Table 1 :

Table 1. From CBT to discerning CBT

\begin{tabular}{|l|l|l|}
\hline \multicolumn{1}{|c|}{ Factor } & \multicolumn{1}{|c|}{ CBT } & \multicolumn{1}{c|}{ Discerning CBT } \\
\hline $\begin{array}{l}\text { Travelers and } \\
\text { their passion }\end{array}$ & $\begin{array}{l}\text { Whoever with adequate passions of } \\
\text { getting in touch with the local } \\
\text { commoners }\end{array}$ & $\begin{array}{l}\text { Limited number of well-educated travelers } \\
\text { with deeper passions of liberating the } \\
\text { commoners toward a self-cultivated } \\
\text { mobilization and civilized embodiment }\end{array}$ \\
\hline $\begin{array}{l}\text { Local } \\
\text { commoners } \\
\text { and their } \\
\text { engagement }\end{array}$ & $\begin{array}{l}\text { Semi-engagement with a certain level of } \\
\text { commoditization of their tradition }\end{array}$ & $\begin{array}{l}\text { Full engagement with the awareness of } \\
\text { liberating and nurturing their tradition as } \\
\text { resources of their own }\end{array}$ \\
\hline $\begin{array}{l}\text { Source of } \\
\text { incomes }\end{array}$ & $\begin{array}{l}\text { Travelers' expenses in accordance with } \\
\text { the the services spent }\end{array}$ & $\begin{array}{l}\text { Co-optation between the commoners and } \\
\text { the travelers, both invest for their goals; the } \\
\text { commoners get their incomes through their } \\
\text { resources' enhancement, the travelers } \\
\text { spend but gain their inspiring experience. }\end{array}$ \\
\hline $\begin{array}{l}\text { Attribute of } \\
\text { service }\end{array}$ & $\begin{array}{l}\text { Co-exploitation through mutual } \\
\text { interaction }\end{array}$ & $\begin{array}{l}\text { Co-investing and co-cultivating for a win- } \\
\text { win juxtaposition }\end{array}$ \\
\hline
\end{tabular}

The discerning CBT travelers know in advance what they are to get, including the services, the price, the environment, the would-be experience and always flexible to manage their traveling arrangement. They look for experience and the performance of life rather than the final manifestation; they enjoy process rather than wellorganized servives. CBT lays a prerequisite framework of social interaction and PM gets it enriched with sense of sharing. It is likely, insofar, PM brings CBT source of inspiration which further stimulates the humane banner of making to live together in good way. 
CBT can be popular worldwide; however, CBT discerning tourism is still a new fashion that just a few places being built. The Santa Claus Village in Finnish Lapland, the waterway village of Giethoorn in the Netherlands, Hahoe village in South Korea, Shirakawago village in Japan, nomadic homestay exploration in Mongolian steppes etc. are likely remarkable circumstances to be researched.

In Southeast Asia, there is not a complete and professional discerning tourism services ever; however, in a popular CBT tourism town the discerning travelers can find their own areas around in town. Hua Hin, Chiang Mai in Thailand, Bagan in Burma, Luang Prabang in Laos, Hoi An and Sapa in Vietnam, Sarawak and Sabah jungle villages in Malaysia, Minangkabau villages, Toraja boat-house villages, Sumba island in Indonesia, Banaue terraced rice field in Northern Philippines etc. all have broader space to pursue the discerning CBT. Furthermore, the agent Exxotissimo has organized hundreds of discerning tourist batches throughout Thailand, Cambodia and Vietnam, 10-25 individuals of each, to go upstream or downstream the Mekong River sytem. Popularly retired professors, engineers or hing-end intellectuals from didfferent higher working uints in North America and Europe are their customers. They love stopping by at along side of the river to breathe the atmostphere of the local lifestyle, join the homemade foods, cultivate as a real farmers and be seated at the universities for academic presentation on the land, the people and the culture of the places they will travel to (or have just traveled).

The following are some random cases of newlyemerging discerning CBT in Vietnam which can be furthered under other multidisciplinary researches - Hoi An and Con Son.

- Hoi An: being a real farmer among the commoners

Hoi An is the $17^{\text {th }}$ century sea-trading port located in Central Vietnam which possesses Vietnamese, Japanese and Chinese styles of architecture. The antique features and the uniqueness have attracted millions of tourists in recent years. However, as Hoi An is connecting to the global tourist network, postmodernism also arrives in this UNESCO-endorsed town. As a result, the local tourism authority set up new form of discerning CBT: living in the $17-18^{\text {th }}$ century town and working like a real farmer.
Just 10 minutes away from the ancient downtown, the discerning travelers can arrive at Tra Que herbal/vegetable cultivation area where they can make up themselves like a $17^{\text {th }}$ century farmer to plough on the cultivated fields or pick up the ready vegetable and prepare for lunch/dinner. A local taste meal is served as the happy ending for a/half day-long working and exploration. Self-earning experience and interaction are always the wanted outcomes of the tourist activities.

- Con Son: when local elites become more vibrant and influential

Con Son is a small-size island in Lower Mekong River system, a municipal unit of Can Tho City, Vietnam. There are around 70 households living on the island, most of them are gradening farmers. The island has been famous for tropical fruit production and slightly well-known fishery materials. Recently, under the impacts of post-modernist wave, urban family set up their trip to the island, making local life a little bit confusing; therefore, there have been a big concern among the local elites. Ramdom tourists arriving can bring wealth, however, the registered agents enjoy the largest marketshare while the unhealthy competition among the commoners makes them more dependent on the agent and seriously damages the communal relationship.

Two years ago, a group of island-born elites working in the nearby Can Tho city who are welltrained children of the local families returned to set up village meeting and designed the island model of discerning CBT. They negotiated with the state authority, the transportation agents (ferry-based form) and local senior association to establish a well-organized structure of service. The tourism agent is totally abandoned from the service network. On the island, a group of 20 households take part in the network, each expertizes in a set of service and cuisine, and one runs differently from the others. For example, the first family focusing on fish service professionally offers flying fish performances, fish-raising stories and experience, fish tales before fish-based cuisine is served; the second family organizes other attractive services by frog raising and frogbased cuisine, and so on the third, the fourth,... The non-registered families can seek for the elites' assistance in case they want to join the network.

Normally a day-long trip can fulfill the travelers's demands by tasting different nuances, 
getting in conversation with different families, gaining various experiences from the island farmers. In return, the local families befome more confident in their gardening and garden-based service. The gardening provides them annual income, however, the garden-based CBT service really brings them wealth. More importantly, the network among the household services helps build the island an integrated society.

\section{CONLUSION}

Along with the global economic development and the rise of standard of living, human kind is entering the golden age of knowledge-based and arts-based civilization. The postmodern tourists require the self-experienced and culturallyembodied participation while travelling; therefore, discerning CBT researches and application are undeniable which bring significant values culturally, ecologicalloy and economically. Postmodern tourists request the multi-directional interaction between the tourists and the local inhabitants, they require the sense of selfrespecting by the hosts which ensure all partners are responsible for environmental protection and sustainable tourism development by the local community. As a real matter, the community in CBT enjoy the larger rights to make the plan, to operate and to control the tourist activities, they are active in dealing with the high-end interlectualistic discerning travelers. In discerning CBT, both economic benefits and moral/civilized performances are the best earnings by the local inhabitants.

Worldwide CBT experience states that each circumstance will bases on its available resources to set up a CBT/CBT-based discerning tourism. The Finnish takes advantage of Santa Claus image to open Lapland Tour, the Dutch utilizes the waterway to set up the water fornt village etc... In Southeast Asia, popular tourism and CBT have been flourishing recently thanks to the Western tourists' start-up. Upon the arrival of postmodernism and discerning CBT fashion, a number of areas in Southeast Asia are setting up to meet the basic requirements, among them, Hoi An and Con Son in Vietnam are remarkable cases. However, the futher academic research for the systematic comprehension and the large-scaled evaluation on the discerning tourism locally should be implemented to investigate the better form of discerning tourism that both can serve the higher demands of intellectualistic travelers and the sustainable development of local cummunities.

\section{REFERENCE}

[1]. APEC Tourism Working Group (2010), Effective Community Based Tourism: A Best Practice Manual, Asia-Pacific Economic Cooperation, Sydney, Australia.

[2]. Butler, R.; Curran, R.; O'Gorman, K.D. (2013), "Propoor tourism in a first world urban setting: Case study of Glasgow Govan", International Journal of Tourism Research, Vol. 15, 443-457.

[3]. Choibamroong, T. (2003). "Knowledge of Tourists' Behavior: A Key Success Factor for Managers in Tourism Business". Advance online publication: http://www.bu.ac.th/knowledgecenter/epaper/jan june20 06/Teardchai.pdf October 2, 2010.

[4]. Cohen, Erik (1988), "Authenticity and commoditization in tourism", Annals of Tourism Research, Vol.15(3), 371-386.

[5]. Donald S. Sutton (2007), "Introduction to the Special Issue: Ritual, Cultural Standardization, and Orthopraxy in China - reconsidering James L. Watson's ideas", Modern China Vol 33 (1), 3-21.

[6]. Eber, S. (1992), Beyond the Green Horizon: A Discussion Paper on Principles for Sustainable Tourism, Godalming, UK: Worldwide Fund for Nature.

[7]. Ellis, S.; Sheridan, L.M. (2014), "The legacy of war for community-based tourism development: Learnings from Cambodia", Community Development Journal, Vol. 49, 129-142.

[8]. Greenwood, D. J (1977), "Culture by the Pound: An Anthropological Perspective on Tourism as Cultural Commoditization", in Hosts and Guests, V. L. Smith, ed., 129-139. Philadelphia: University of Pennsylvania Press.

[9]. Haanpaa, L. (2005), "Postmodern and Structural Features of Green Attitudes and Consumption", Series Discussion and Working Papers 2005 from National, European, Global Research Seminars of Economic Sociology 2004.

[10]. Hall, C.M. (1996), Introduction to Tourism in Australia: Impacts, Planning and Development, Addison Wesley Longman: Melbourne, Australia.

[11]. Ian Yeoman (2008), Tomorrow's Tourist: Scenarios and Trends, Oxford, U.K. Elsevier Ltd.

[12]. James Watson (1985), Standardizing the gods: the promotion of T'ien Hou ("Empress of Heaven") along the South China coast, 960-1960, in Popular Culture in Late Imperial China, edited by David Johnson, Andrew Nathan, and Evelyn Rawski, Berkeley: University of California Press, p. 292- 324.

[13]. Leonard Barnett \& Edward G. L. Carter (2013), "A Critique of the discerning traveler: tourism, sustainability and discerning traveler", in Proceeding of the International Conference on $70^{\text {th }}$ Anniversary of Silpakorn University, Bangkok.

[14]. Lucchetti, V.G., Font, X. (2016), "Community based tourism: Critical success factors", Advance online publication: $\quad$ www.icrtourism.org/wpcontent/uploads/2012/03/OP27.pdf (accessed on 15 September 2017)

[15]. Lyotard, Jean-Francois (1984), The Postmodern Condition: A Report on Knowledge, University of Minnesota Press. 
[16]. MacCannell, D. (1973), "Staged Authenticity: Arrangements of Social Space in Tourist Settings", American Journal of Sociology 79(3): 589-603.

[17]. MacCannell, D. (1999), "The Tourist", A New Theory of the Leisure Class, University of California Press.

[18]. Manyara, G.; Jones, E. (2007), "Community-based tourism enterprises development in Kenya: An exploration of their potential as avenues of poverty reduction", Journal of Sustainable Tourism 15, 628-644

[19]. Michael Szonyi (2002). Practicing kinship: lineage and descent in late imperial China. Stanford, CA: Stanford University Press.

[20]. Murphy, P.E (1985), Tourism: A Community Approach, Methuen: New York, NY, USA.

[21]. Netherlands Development Organization (SNV) Asia ProPoor Sustainable Tourism Network (2007), A Toolkit for Monitoring and Managing Community-Based Tourism, SNV Asia Pro-Poor Sustainable Tourism Network and Griffith University: Queensland, Australia.

[22]. Nguyen Ngoc Tho (2015), "The postmodern tourism", The globalization and localization in tourism, VNUHCM Press, 82-96.

[23]. Oxford University (1998), New Oxford American Dictionary, Oxford University Press.

[24]. Paul Katz (2007), "Orthodopraxy and heteropraxy beyond the state - standardizing ritual in Chinese society", Modern China, Vol 33: 1, 71-90.

[25]. Perionova, I. (2005), "Where Are You Going, Where Have You Been", In Internet-Zeitschrift für Kulturwissenschaften, No. 16. Advance online publication: http://www.inst.at/trans/16Nr/05 6/perianova16.htm

[26]. Pomeranz, Kenneth (2007), "Orthopraxy, orthodoxy, and the Goddess(es) of Taishan", Modern China, Vol. 33: 1, $22-46$.

[27]. Scheyvens, R. (1999), "Ecotourism and the empowerment of local communities", Tourism Management 20, 245-249.

[28]. Scheyvens, R. (2002), Tourism for Development: Empowering Communities, Prentice-Hall: Harlow, UK.

[29]. Singh, T. V. (2004), New Horizons in Tourism: Strange Experiences and Stranger Practices, UK: Wallingford

[30]. Tepalus, C. (2000), Aiming for Sustainability in the Tour Operating Business, International Institute for Industrial Environmental Economics, Lund University, Lund, Sweden. IIIEE Reports: 16.

[31]. Tek B. Dangi \& Tazim Jamal (2016), “An Integrated Approach to "Sustainable Community-Based Tourism", Sustainability Vol.8(5), p. 475 .

[32]. Thanh Phong (2011), Sat thu dau mung mu, Fine Arts Publishing House.
[33]. Tribe, J. (2006), "The Truth about Tourism", Annals of Tourism Research, Vol. 33, No.2, 360 - 381.

[34]. Urry, J. (2002), The Tourist Gaze, London: Sage.

[35]. Weaver, D. (2010), "Community-based tourism as strategic dead-end", Tourism Recreation Research Vol. $35,206-20$.

[36]. Wilson, R (1991), "Is Postmodern Performance Possible?", Theatre Journal, Vol. 43, No. 1 (March), 1440.

[37]. Wong, R. Bin, Theodore Huters, \& Pauline Yu (1997), Culture and state in Chinese history: conventions, accommodation, and critiques, Stanford, CA: Stanford University Press.

[38]. World Travel \& Tourism Council (2012), "The Economic Impact of Travel \& Tourism 2012", Advance online publication: http://www.wttc.org.

Nguyen Ngoc Tho is an associate professor in Vietnamese and East Asian Cultural Studies of Faculty of Cultural Studies, USSH, VNU-HCM. He received his B.A. in Chinese studies in 1999, M.A. in 2003 and Ph.D. in 2012. He undertook a six-month internship at NUS in 2001, six-month and then nine-month fellowships at Sun Yat-sen University (China) in 2005 and 2008; an 18month fellowship at the Harvard-Yenching Institute in 2007 and 2009, and currently a 10month grant as a visiting scholar at the HarvardYenching Institute, USA (2017-2018). He earned the title "associate professor" in March 2018. He published three books and several papers. He was a participant in the US Government Visitors Program in Higher Education in 2015. He is currently focusing on cultural transformation of social rituals in Vietnam and East Asia, and absorbs the findings in building modern education in Vietnam under the artistic and humanistic way. $\mathrm{He}$ has conducted the project Innovation on the teaching methodology in Dong Thap province (2014-2016) and partly in An Giang (2017). He currently works on the research project "Taking root wherever you land: the transformation and indigenization of the ethnic Chinese in contemporary Vietnam" (2018-2019). 


\title{
Hướng tới loại hình du lịch sành điệu
}

\author{
Nguyễn Ngọc Thơ \\ Trường Đại học Khoa học Xã hội và Nhân văn \\ Email tác giả liên hệ: ngoctho@hcmussh.edu.vn \\ Ngày nhận bản thảo: 12/12/2017; ngày chấp nhận đăng: 25/1/2018; ngày đăng: 30/3/2018
}

Tóm tắt-Du lịch cộng đồng được khởi xướng từ phương Tây, hiện đang phát triển khá mạnh mẽ nhờ vào sự phát triển của công nghệ thông tin. Du khách cộng đồng đã và đang tạo nên nhiều nguồn lực mới thúc đẩy hoàn thiện các mô hình du lịch cộng đồng trên thế giới. Cùng với sự bùng nổ công nghệ và những tác động của chúng vào trong bộ óc con người, chủ nghĩa hậu hiện đại hình thành do nhu cầu giải phóng tư duy nhân loại và đa dạng hóa lối sống trong mối quan hệ tương tác giữa các nguồn lực sinh thái và văn hóa. Chủ nghĩa hậu hiện đại bắt đầu từ trong nghệ thuật và kiến trúc, dần dà ảnh hưởng tới kinh tế và du lịch, do vậy nó cũng chi phối du lịch cộng đồng. Sự phối họ̣p giữa di lịch cộng đồng và chủ nghĩa hậu hiện đại cho ra đời loại hình du lịch sành điệu dựa vào cộng đồng (gọi tắt là du lịch sành điệu) dành cho những du khách sành điệu vốn là những người chú trọng đến sự tự thân trải nghiệm, tự thân khám phá thế giới trong quá trình du lịch, đồng thò̀i họ cũng đòi hỏi sự chung tay chia sẻ trách nhiệm và lợi ích giữa khách du lịch, đại lý du lịch và cộng đồng địa phương. Du khách sành điệu luôn mong muốn thúc đẩy nhận thức và vai trò, trách nhiệm tự thân của cộng đồng trong việc nâng cao đời sống và nếp sống văn minh của chính họ. Du lịch sành điệu không thể thay thế hoàn toàn du lịch cộng đồng song có thể góp phần làm đa dạng hóa ngành du lịch đương đại bởi nó đáp ứng một phần nhu cầu có thật của du khách và đặc biệt là khả năng đóng góp thúc đẩy cuộc sống nhân loại.

Tù khóa-du lịch cộng đồng, hậu hiện đại, du lịch sành điệu, phối hợp, tương tác. 